\title{
A TRIBUTE TO PROFESSOR ZHANG CHANGSHOU 張長壽 (1929-2020)
}

\author{
Li Feng *
}

\begin{abstract}
Zhang Changshou was one of the most important archaeologists of modern China, and a founder of Western Zhou archaeology. Zhang is particularly well known as the author of a series of works that established the chronology of the Western Zhou material culture and is esteemed for his excellent scholarship also on bronzes and jade objects, characterized by a strong basis in field archaeology. Among his academic appointments are Director of the Feng-Hao Archaeological Team in 1963-1988, and Associate Director of the Institute of Archaeology (Chinese Academy of Social Sciences) in 1985-1988. Zhang was also a pioneer of Sino-American collaboration (with Harvard University) in field archaeology and was elected a Corresponding Member of the German Archaeological Institute in 1988. Zhang passed away in Beijing on January 30, 2020. This article summarizes his academic accomplishments.
\end{abstract}

Professor Zhang Changshou 張長壽 (Figure 1), one of the founders of Western Zhou archaeology, but widely esteemed also for his scholarship on ancient Chinese bronzes, passed away in Beijing on January 30, 2020. Born in Shanghai on May 6, 1929, Professor Zhang's long career that culminated in his standing as an eminent member of the Institute of Archaeology (Chinese Academy of Social Sciences), ${ }^{1}$ and a leading figure in Chinese archaeology, began his education at the missionary St. John's High School. This consequently led to his enrollment in St. John's University (Shanghai) in 1948, where he was majored in mathematics initially, but soon was transferred to the Department of History, to study Western history under Professor Donald Roberts. On the departure of Professor Roberts, by the next year Zhang was relocated in Beijing, where he pursued a degree then in Chinese history at Yenching University. After his graduation in summer 1952, Zhang taught in a high school in Beijing affiliated with Tsinghua University until he was recruited by the Institute of Archaeology, Chinese Academy of Sciences, in July 1956.

*Li Feng, 李峰, Columbia University, fl123@columbia.edu

1. Zhang Changshou served as the Associate Director of the Institute of Archaeology, Chinese Academy of Social Sciences, in 1985-1988, and prior to it, as the Director of the Institute's Shang-Zhou Archaeology Project.

(C) The Society for the Study of Early China and Cambridge University Press 2021 


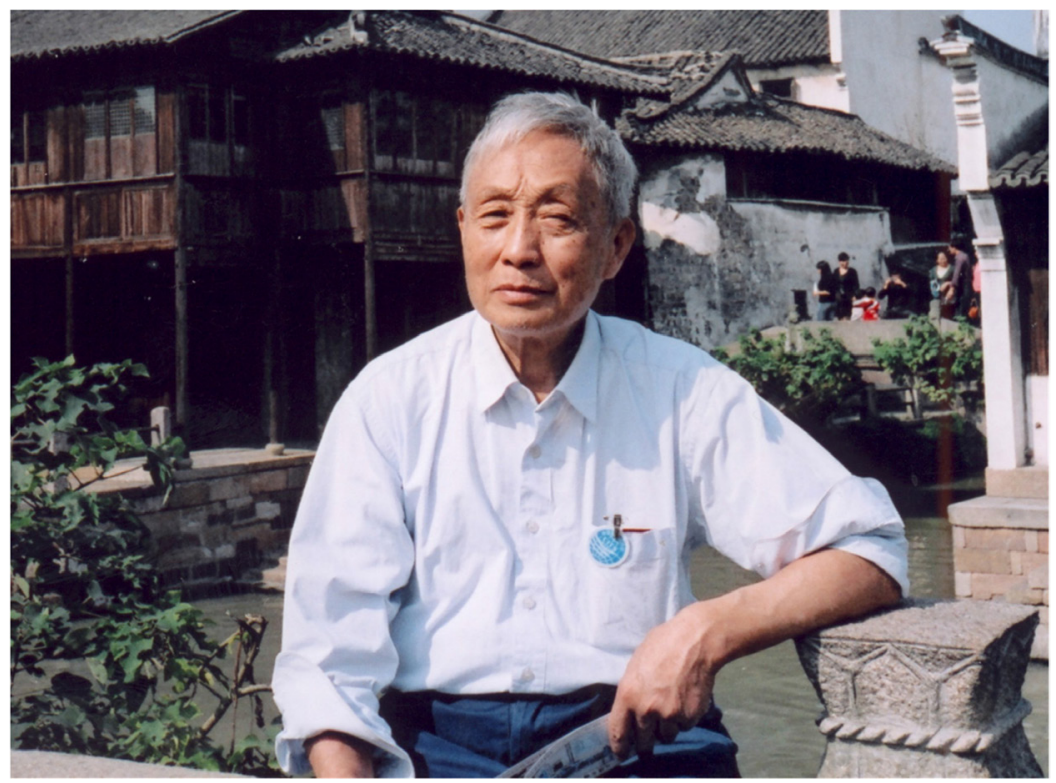

Figure I Professor Zhang Changshou (photo courtesy the Institute of Archaeology, CASS).

During his long career at the Institute of Archaeology, Professor Zhang conducted extensive fieldwork in provinces in northern China, but nowhere was more central to his scholarship than the Western Zhou (1045-771 B.C.E.) capital sites Feng and Hao in central Shaanxi, where he spent more than thirty years, first as a young research fellow and soon as the director of the archaeological team from 1963 to 1988 . Beginning with the analysis of the results of the initial excavation at Zhangjiapo 張家坡 in 1955-1957, Zhang was largely responsible for the establishment of the chronological standards of Western Zhou remains (published in 1962), which was then refined through two major excavations thereafter in 1967 and 1983-1986, directed by Zhang himself. Due to the central position of the site in the political-cultural complex of the Western Zhou, this work has contributed a solid foundation to Western Zhou archaeology. More importantly, the basis of fresh data from nearly 700 Western Zhou tombs that informed the work of Zhang and his colleagues provided a methodological alternative to the then-popular methodology of dating in Chinese archaeology that equated tomb chronology to pottery typology. Instead, Zhang's approach takes into consideration the wider context of the burial and emphasizes changes in the composition of the pottery assemblage that reflects first of all burial ritual. In other words, he preferred analyzing the transition in vessel types to the typological evolution of pottery as evidence for dating. 
Professor Zhang's scholarship on bronzes shows deep imprints of his experience as a field archaeologist, and this enabled him to stand out against a long tradition that began with Guo Moruo that has focused on the analysis of the inscriptions as the starting point for further research, and also from the Western art historical tradition. Simply speaking, Zhang applied the method of analyzing burial pottery to the study of bronzes which, when scientifically excavated in groups, provided the most important evidence for dating. This approach is typically found in his famous study of the uninscribed bronze vessels of the Shang period (1554-1046 B.C.E.) and before, from Erlitou to Anyang. According to him, the development of burial bronzes in Anyang during the late Shang passed through three different stages, whereas previous studies proposed a four-period division of the local burial pottery at Anyang. On the other hand, Zhang showed a special interest in bronze objects from the regional polities, such as the Yachou 亞醜 bronzes from Shandong, dating to late Shang, or the mid-Shang bronzes from Xingan 新幹 in Jiangxi about which he published an English article in East Asian Archaeology (No. 2, 2000), or the unique bronze groups from the cemeteries of the state of $Y u$ 魥 in Baoji in western Shaanxi. In such studies, his interests are more in the culture than the bronzes, which provided evidence for interregional contacts.

Another important contribution of Professor Zhang's lies in his ingenious research on chariots in ancient China. Since the 1950s, remains of wooden chariots of the Shang through the Warring States period have been excavated in large numbers. This called for correlative study of information about the chariot in the contemporaneous inscriptions, with reference also to the descriptions of chariots in the Warring States to Han texts, in order to fully understand the social roles of chariots and the ritual institutions that regulated their construction in the Western Zhou. Beginning with the study of the jingle bells (luan 鑾) and axle cap (jinyong 金角) in 1962, and concluding with his meticulous analysis of chariot wheels and boxes in 1994, Zhang produced a series of studies that together formed a systematic new account of the chariot in archaeology. At the same time, Professor Zhang is also known for a series of studies of jades, based on discoveries of jade objects in Western Zhou tombs, that formed the basis for identifying their names in the texts.

Professor Zhang Changshou's work shows the strong tendency toward using field archaeology as the primary channel to deliver the final verdict on many long disputed terms in the transmitted ritual texts. In most cases it was the misinformation in the texts, or the misinterpretation of the ambiguous textual records by Qing-modern scholars, that were rightly corrected through archaeological excavation. 
A good example of this is Zhang's study of the supporting wooden beam ( futu 伏兔), located above the axle and under the chariot box, and the bronze axle covering (huamin 畫 䡖). These had been previously misplaced by Hayashi Minao, but Zhang correctly repositioned them based on the excavation of chariots at Liulihe 琉璃河 and Zhangjiapo. More importantly, excavated objects were used as a basis for authenticating and dating the unprovenanced bronzes or jade objects in the public and private collections outside China, as is typical in his studies of the jade masks and toothed jade circlets (xuanji 璇璣). In short, Zhang's work has given the long tradition of studies of ritual objects and ritual institutions a confirmed archaeological base.

Professor Zhang Changshou should also be credited for his efforts to keep a window open to overseas studies of Chinese archaeology, especially in the field of bronze studies, in the thirty years after the death of Chen Mengjia, when China was completely closed to the outside world. Taking advantage of the small foreign language acquisition in archaeology by the Institute of Archaeology, the only location where such sources could be found in China, he took the time to translate or introduce works by American and Japanese scholars, such as Thomas Lawton's study of the Taibo gui 太保筬 at the Freer Gallery and Ito Michiharu's study of the newly discovered Qiuwei 雸衛 bronzes in Shaanxi.

He was also a pioneer of international collaboration, when projects of such nature became possible in the 1980s. The return of the late Professor Kwang-chih Chang to China in 1984 gave opportunities later for negotiation to collaborate between Harvard University and the Institute of Archaeology. In the seven years from 1990 to 1997, Shangqiu 商丘 in eastern Henan became the hotspot of international collaboration as well as multidisciplinary archaeological exploration in China, with Zhang serving as the Chinese director of the joint team and Chang as its American director. The project employed new radarbased survey technologies and aimed at locating pre-dynastic Shang culture in the region, using K. C. Chang's theory, which at that time was at odds with the mainstream view among the Chinese scholars, which pointed to northern Henan and southern Hebei as the predynastic Shang center. This speaks well of Professor Zhang's openness to exploring new interpretation and new technology. The project led to the discovery of the capital city of the state of Song, which dates to the Warring States period, and also resulted in the completion of a number of doctoral dissertations in American universities. At the conclusion of the fieldwork in 1997, Professor Zhang personally escorted the artifacts and various research samples derived from the fieldwork back to the institute in Beijing, and thereafter spent many years analyzing the data 
and editing the project's archaeological report, which he was finally able to see published in 2017, three years prior to his death.

Professor Zhang made three trips to the United States, though he was a less frequent traveler to this country than some other important figures in the field such as Professor Li Xueqin 李學勤. Zhang's first trip was in June 1980, when he attended the opening ceremony of the "Great Bronze Age of China" exhibition at the Metropolitan Museum of Art in New York, together with Xia Nai 夏舀, Ma Chengyuan 馬承源, and Zhang Zhenglang 張政烺. On the way home, the group participated in a conference at Berkeley, California (Figure 3). The second trip took place in summer 1995, amid the on-going Shangqiu survey and excavation project, when he and colleagues from the Institute of Archaeology were invited by K. C. Chang to visit Harvard University. In March 2000, Professor Zhang and colleagues presented the results of the "Xia-ShangZhou Chronology Project" in a panel at the AAS annual conference in Washington DC. Afterwards, he, Qiu Shihua 仇士華, and Zhang Peiyu 張培瑜 attended the "Creel Annual Lecture" of that year, given by David Nivison at the University of Chicago, and after it a workshop on the chronology of Early China hosted by Professor Edward L. Shaughnessy.

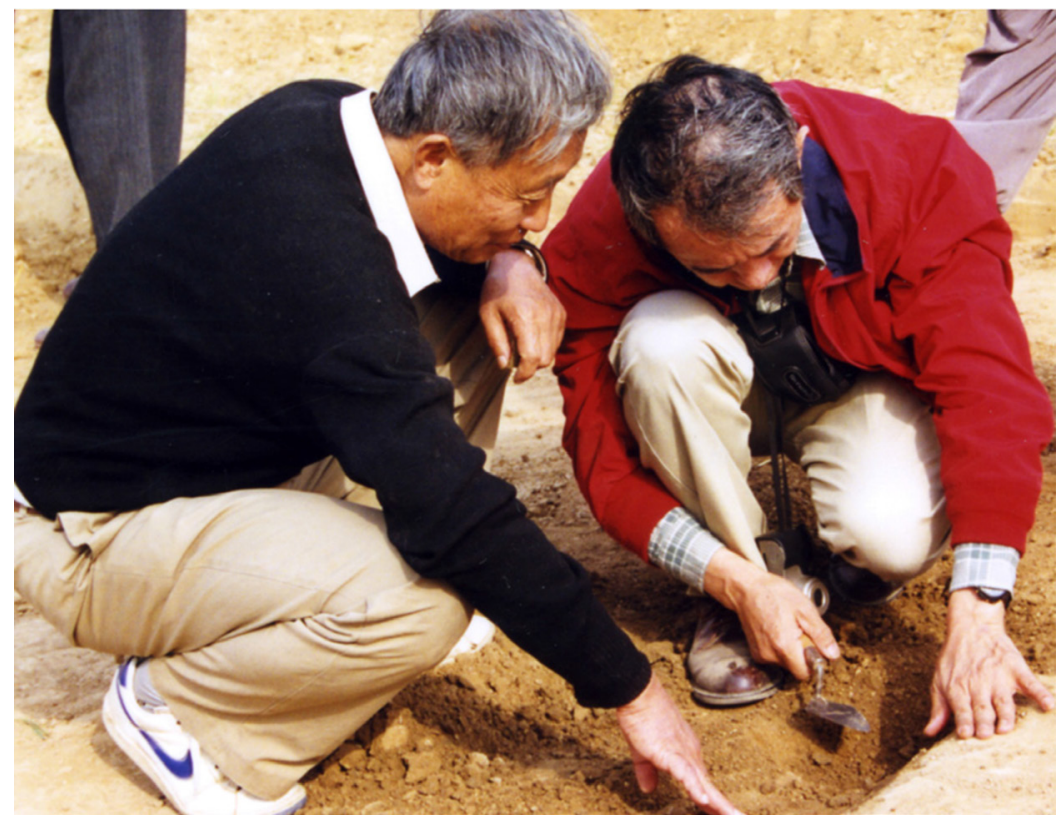

Figure 2 Professors Zhang Changshou (left) and Kwang-chih Chang (right) at excavation in Shangqiu, October 1997, photography by Zhichun Jing (courtesy Tang Jigen). 


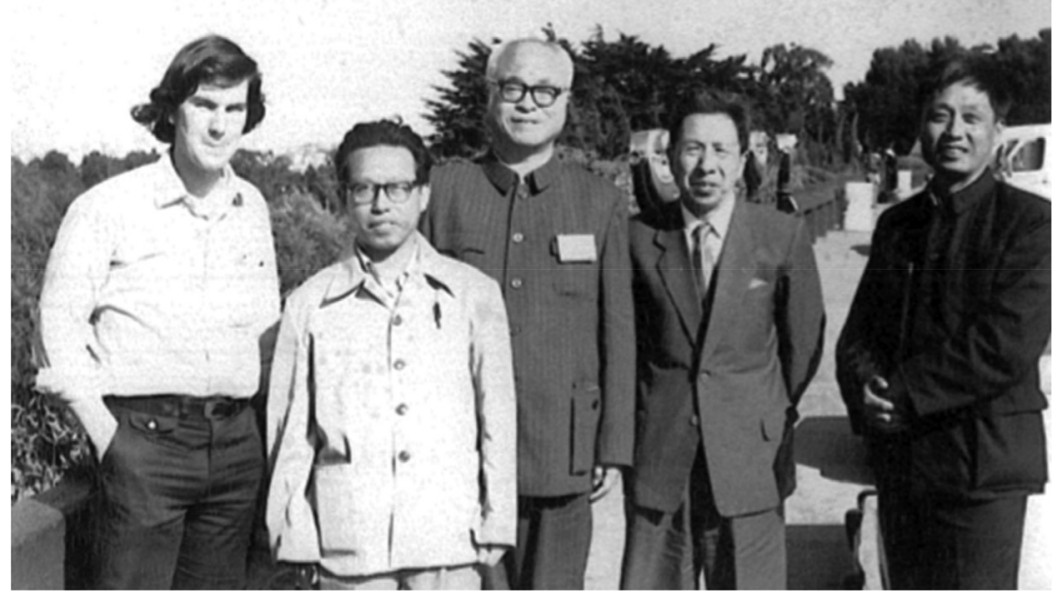

Figure 3 At the Berkeley conference, 1980. From right to left: Zhang Changshou, Xia Nai, Zhang Zhenglang, Ma Chengyuan, and Edward L. Shaughnessy (photo courtesy Edward L. Shaughnessy).

\section{紀念張長壽先生}

李峰

\section{提要}

張長壽先生是現代中國最重要的考古學家之一，也是西周考古的奠基 人。張長壽特別以他確定了西周物質文化分期的一系列研究而著名, 而他以田野考古爲基礎對商周青銅器和玉器的出色研究更是廣受學 者們推崇。張於 1963-1988 年擔任豐鎬考古隊隊長, 并於 1985-1988 年擔任中國社會科學院考古研究所副所長。張長壽也是一位中美田野 考古合作 (哈佛大學) 的開創者; 他於 1988 年被選爲德意志考古研究 所通訊院士。張長壽於 2020 年 1 月 30 日在北京逝世。本文概括了他 的學術貢獻。

Keywords: Tribute, Zhang Changshou, archaeology, bronzes, Western Zhou 紀念, 張長壽, 考古, 青銅器, 西周 